\title{
Physiological and biochemical performance of almond trees under deficit irrigation
}

\author{
Iva Prgomet $^{\mathrm{a}, *}$, Núria Pascual-Seva ${ }^{\mathrm{b}}$, Maria Cristina Morais ${ }^{\mathrm{a}}$, Alfredo Aires ${ }^{\mathrm{a}}$, David Barreales ${ }^{\mathrm{c}}$, \\ António Castro Ribeiro ${ }^{c}$, Ana Paula Silva ${ }^{a}$, Ana I.R.N.A. Barros ${ }^{\mathrm{a}}$, Berta Gonçalves ${ }^{\mathrm{a}}$ \\ ${ }^{a}$ Centre for the Research and Technology of Agro-Environmental and Biological Sciences, CITAB, University of Trás-os-Montes e Alto Douro, UTAD, Quinta de Prados, \\ 5000-801, Vila Real, Portugal \\ ${ }^{\mathrm{b}}$ Department of Plant Production, Universitat Politècnica de València, 46022 València, Spain \\ ${ }^{\mathrm{c}}$ Centro de Investigação de Montanha (CIMO), Instituto Politécnico de Bragança, Campus de Santa Apolónia, 5300-253 Bragança, Portugal
}

\section{A R T I C L E I N F O}

\section{Keywords:}

Gas exchange

Photosynthetic pigments

Sugars

Starch

Proteins

Plant hormones

\begin{abstract}
A B S T R A C T
The almond tree is generally recognized as drought-tolerant, though it depends on water resources to achieve high yields. During the summer months of two consecutive years, several physiological and biochemical parameters were observed, to understand the almond tree's seasonal sensitivity and behavior under different irrigation strategies based on crop evapotranspiration (ETc): T100 optimal water requirement regime (applying 100\% ETc); T70 and T35 sustained deficit irrigation regimes (applying 70\% and 35\% ETc); T100-35 regulated deficit irrigation regime (reducing the application to 35\% ETc during fruit filling stage); and T0 (rainfed). The total leaf chlorophyll and carotenoid reduction in T0 and T35 treatments was significant compared to T100-35. Leaf soluble proteins and total soluble sugar contents were significantly higher in non-irrigated trees compared to other treatments, while the starch content showed the opposite trend. Rainfed trees were under obvious water stress, displaying the lowest values for relative water content (RWC), stomatal conductance (gs), photosynthetic rate (A), and transpiration rate (E), and the highest for intrinsic water use efficiency (A/gs). Plant hormones (ABA and IAA) generally accumulated more in non-irrigated trees. The almond tree has been confirmed as a drought-tolerant species, and when water is scarce, reducing the water application to $35 \%$ ETc during fruit filling stage, results in no yield losses, and the plant status remains unstressed. However, to get the maximum crop potential, in years and areas where water is not restricted, full irrigation requirements have been shown to boost almond tree performance.
\end{abstract}

\section{Introduction}

Water scarcity and drought phenomena are rapidly spreading worldwide. In the Mediterranean basin, the situation is still not critical, but signs of water shortage and drought are present, with frequent prolonged periods without rain. Furthermore, due to the enormous growth in the human population, potential future scarcities of water resources are on the rise (WWAP, 2015).

Plant response to drought depends on the nature of the water shortage, and includes different physiological and biochemical responses, acclimatization and finally adaptation to drought (Yadollahi et al., 2011). The use of water-saving tools such as deficit irrigation strategies has been encouraged by the European Water Framework
Directive 2000/60 (The European Parliament and the Council of the European Union, 2000).

The almond (Prunus dulcis (Mill) D.A. Webb) is grown in semiarid areas exposed to long periods of drought and high temperatures. It is a species generally recognized as able to grow in conditions of water shortage, without requiring irrigation. However, yield is directly related to tree performance, and greatly depends on water availability at critical seasonal stages (Egea et al., 2010). To promote the sustainable growth of almond trees, an array of irrigation management practices has been proposed to improve water usage and productivity, such as managing deficit irrigation based on crop evapotranspiration. Deficit irrigation is probably one of the most used strategies, where the applied water is reduced to under the optimal level for trees' full requirements

\footnotetext{
* Corresponding author.

E-mail addresses: ivap@utad.pt (I. Prgomet), nupasse@prv.upv.es (N. Pascual-Seva), cmorais@utad.pt (M.C. Morais), alfredoa@utad.pt (A. Aires), davidsantos@ipb.pt (D. Barreales), antrib@ipb.pt (A. Castro Ribeiro), asilva@utad.pt (A.P. Silva), abarros@utad.pt (A. I.R.N.A. Barros), bertag@utad.pt (B. Gonçalves).
} 
(English, 1990). Among deficit irrigation strategies, the regulated deficit irrigation is based on reducing the irrigation just during some periods when the crop is less sensitive to water stress (Girona et al., 2005). Almond trees are reported to be relatively tolerant to stress during kernel filling stage (Goldhamer and Viveros, 2000). With the aim to identify the most efficient irrigation method for almond trees, some studies have been carried out so far (Egea et al., 2009, 2010, 2013; Goldhamer et al., 2006; Girona et al., 2005; Zhu et al., 2015). Deficit irrigation in almond trees led to water savings, despite not showing increase in yield (Egea et al., 2010; Girona et al., 2005; Romero et al., 2004). Furthermore, farmers' decision of using the deficit irrigation lies also in the fact whether the potential decreased yield may be compensated by the decreased costs of applying less irrigation water. Data on the tree's physiological and biochemical status under different water conditions may lead to better understanding of processes that are happening and to help produce a stable crop yield and influence the quality of the final product.

Abiotic stresses caused by drought, among other factors, directly impact photosynthesis by disrupting photosynthetic components, including carbon fixation, stomatal conductance, and photosynthetic pigments (Ashraf and Harris, 2013). Under drought stress, the synthesis of photosynthetic pigments is usually negatively affected, and degradation often occurs (Farooq et al., 2009). The most immediate response by plants to stress is stomatal closure, which reduces the transpiration rate and $\mathrm{CO}_{2}$ assimilation, and decreases the availability of $\mathrm{CO}_{2}$ for further photosynthetic processes (Farooq et al., 2009), affecting the carbohydrate status of the plants and finally the yield. Furthermore, as intrinsic water use efficiency is directly related to stomatal conductance, it typically increases under drought conditions. All these responses occur under the action of abscisic acid (ABA), a phytohormone triggered by drought stress, and known as the 'plant stress hormone'. It plays an important role in inducing stomatal closure due to its part in the signal transduction network in guard cells (Tuteja, 2007). Abscisic acid may also play an important role in the regulation of starch behavior during osmotic stress in plants, by controlling the activity of enzymes responsible for starch degradation (Thalmann et al., 2016). On the other hand, many species accumulate soluble sugars in response to stressful environmental conditions, thus contributing to osmotic adjustment in the cells of stressed plants (Mohammadkhani and Heidari, 2008). However, variations in environmental conditions may also lead to a major decrease in photosynthetic efficiency, reducing the supply of soluble sugars to sink tissues (Rosa et al., 2009). Stress may induce the synthesis of a variety of proteins, leading to an increase in the total content of soluble proteins, while can also have a negative effect on protein synthesis (Dubey, 1999).

Almond is a drought-tolerant species that can grow in conditions of water shortage, however, to achieve the crop's best performance, water is indispensable need. Therefore, the main aim of this study was to get to know how different deficit irrigation strategies influenced the summer physiological and biochemical status of almond trees grown in Northern Portugal.

\section{Materials and methods}

\subsection{Experimental trial}

The experiment was carried out in a 15 year-old commercial almond orchard located in Alfândega da Fé, Portugal $\left(41^{\circ} 21^{\prime} \mathrm{N} ; 6^{\circ} 56^{\prime} \mathrm{W} ; 576 \mathrm{~m}\right.$ above sea level), during 2015 and 2016. Studies were conducted on the late blooming French variety 'Ferragnès'. It is a water-sensitive almond variety (Karimi et al., 2013), well adapted to Portuguese agro-climatic conditions and often grown there for the nutritional and sensorial properties of its kernel and high yield. The almond trees were all grafted on GF-677 rootstock and spaced $6 \times 4 \mathrm{~m}$ apart. The experiment followed a randomized block design, with four $(n=4)$ replications, each experimental unit consisting of three trees (in total $n=12$ trees treatment ${ }^{-1}$ ). The trees had been irrigated following local practices since planting. Trees were drip irrigated when planted and during the 1 st and 2nd year, with 2 irrigation events per day in summer months, particularly when the conditions were more severe. Afterwards, the local practice is to irrigate trees depending on the weather conditions, irrigating, on average, once to two times per week.

Different irrigation treatments were assayed based on crop evapotranspiration (ETc): T100 optimal water requirement regime (applying $100 \%$ of ETc); T70 and T35 sustained deficit irrigation regimes (applying $70 \%$ and $35 \%$ of ETc); T100-35 regulated deficit irrigation regime (100\% ETc during fruit development, reducing the application to $35 \%$ ETc during fruit filling); and T0 (rainfed). Irrigation season began when the predawn leaf water $\left(\psi_{\mathrm{pd}}\right)$ potential reached values in range -0.4 to $-0.5 \mathrm{MPa}$ (mean value for well-watered almond trees in stage IV-kernel-filling (Egea et al., 2010; Girona et al., 2005)). Irrigation season started earlier in 2015, given the important rainfalls registered in spring 2016. ETc was estimated using the FAO Penman-Monteith equation for reference evapotranspiration (ETo) and a crop coefficient (Kc) of 0.9 (for the mid-season stage, Allen et al., 1998). An evaporation reduction coefficient $(\mathrm{Kr}=0.65)$ was calculated according to the equation of Ferreres et al. (1981) $\left(\mathrm{Kr}=\left(3.05+2.558 \times \mathrm{C}-0.016 \times \mathrm{C}^{2}\right)\right.$ / 100), with $\mathrm{C}$ as the ground cover in this experiment corresponding to $29.5 \%$. The ground cover was obtained by measuring the shaded area (A) outlined from the horizontal projection of the tree canopy. The average diameter of the tree canopy (D) was measured in one hundred and thirty trees. The percentage of ground cover was estimated dividing the shaded area $\left(\mathrm{A}=\pi \mathrm{D}^{2} / 4\right)$ by tree spacing $(\mathrm{C}=\mathrm{A}$ /tree spacing $\mathrm{x}$ $100)$. Values for ETo were obtained from the automatic weather station (AWS) located near the orchard (Table 1). The AWS is equipped with sensors for measuring air temperature and relative humidity (Vaisala HMP155A-L, Campbell Sci), solar radiation (Skye SP1110, Apogee Instruments), wind speed and direction (03,002 Wind Sentry, R.M.Young), and precipitation (Rain-O-Matic Small, Pronamic). Data is stored on a CR800 datalogger (Campbell Sci).

Irrigation water was applied through a drip irrigation system with pressure-compensated emitters of $3.6 \mathrm{Lh}^{-1}$ with $1 \mathrm{~m}$ line spacing (4 emitters per plant). The frequency of water applications was the same for all treatments and varied from 2 to 3 days per week applied continuously until harvest. Emitters flow and water uniformity distribution were evaluated during the experiment.

Table 1

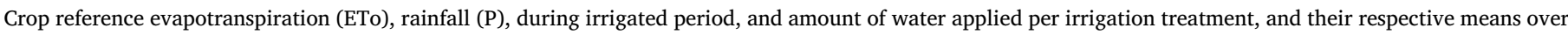
the period.

\begin{tabular}{|c|c|c|c|c|c|c|}
\hline \multirow[t]{2}{*}{ Year } & \multirow[t]{2}{*}{ ETo (mm) } & \multirow[t]{2}{*}{$\mathrm{P}(\mathrm{mm})$} & \multicolumn{4}{|c|}{ Irrigation treatments (water applied, mm) } \\
\hline & & & $\mathrm{T} 100$ & T100-35 & T70 & T35 \\
\hline 2015 & 534.6 & 90.2 & 325.9 & 193.1 & 217.3 & 108.6 \\
\hline 2016 & 482.7 & 25.2 & 294.3 & 153.4 & 196.2 & 98.1 \\
\hline Average 2015-2016 & 508.7 & 57.7 & 310.1 & 173.3 & 206.8 & 103.4 \\
\hline
\end{tabular}




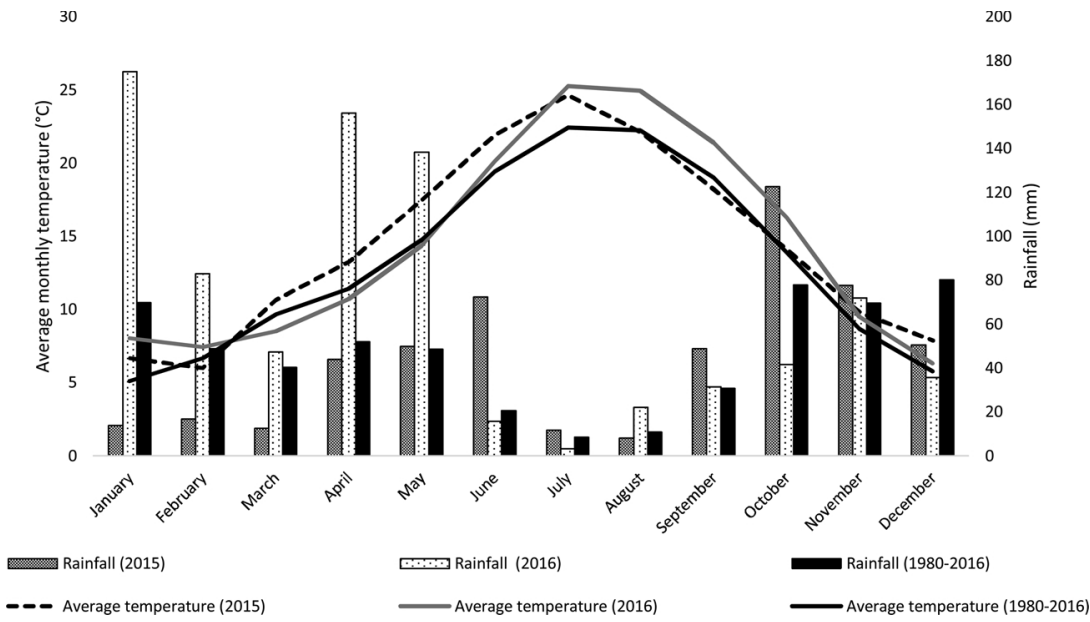

Fig. 1. Average monthly temperature $\left({ }^{\circ} \mathrm{C}\right)$ and rainfall (mm) in 2015, 2016 and 1980-2016 average.

The climate at the production site is classified as Csb by Köppen and Geiger; Mediterranean with hot, dry summers. Average annual rainfall is $557 \mathrm{~mm}$, with minimum rainfall during the summer months (average rainfalls in July and August are 8 and $11 \mathrm{~mm}$, respectively). The warmest months are July and August, with average daily temperatures of $22{ }^{\circ} \mathrm{C}$, while the coldest month is January, with an average daily temperature of $5{ }^{\circ} \mathrm{C}$. The climate data for average values for 1980-2016 were obtained from the E-OBS gridded dataset (Haylock et al., 2008). The main climate data for the 2015 and 2016 seasons were taken from an automatic weather station in the orchard and are presented in Fig. 1. In 2015 , the average daily temperature was $25^{\circ} \mathrm{C}$ in July and $22^{\circ} \mathrm{C}$ in August, while precipitation was 12 and $8 \mathrm{~mm}$ in July and August, respectively. In 2016, the average temperature was $25^{\circ} \mathrm{C}$ in both July and August, and rainfall was 7.8 and $22 \mathrm{~mm}$ in July and August, respectively. In addition, 2016 was a year with greater than average rainfall in spring and low temperature extremes in late spring (Fig. 1).

\subsection{Plant water status}

To determine the leaf water status, two leaves per tree were placed in Falcon tubes and closed on site. In the laboratory several parameters were examined: fresh weight (fw), turgid weight at full turgor (tw) (measured after immersing the leaf petioles for $24 \mathrm{~h}$ in deionized water at $4{ }^{\circ} \mathrm{C}$ and in the dark) and dry weight $(\mathrm{dw})$ (measured after drying at $70^{\circ} \mathrm{C}$ to a constant weight). Relative water content (RWC) was calculated as followed: RWC $(\%)=(\mathrm{fw}-\mathrm{dw}) /(\mathrm{tw}-\mathrm{dw}) \times 100$. The RWC measurements were taken on three dates of each season (22 July, 12 August and 14 September in 2015, and 28 July, 18 August and 12 September in 2016).

Tree water status was also assessed through the determination of predawn leaf water potential (2015) and stem leaf water potential (2016). Leaf water potential was measured in fully expanded leaves (12 per treatment of six representative plants) with a pressure chamber (Model 1000, PMS Instrument Company, Albany, USA) according to the method of Scholander et al. (1965). For stem leaf water potential determination, selected mature leaves near the trunk were wrapped in small bags covered with aluminium foil at least $1 \mathrm{~h}$ prior to measurement. In 2015 the measurements were taken on three dates (27 July, 10 and 31 August) and in 2016 were taken on four dates (20 June, 18 July, 8 and 25 August).

\subsection{Photosynthetic pigment determination}

For the chlorophyll and carotenoid determination, leaf discs were ground with a pestle and mortar using acetone/distilled-water $(80 / 20$, $\mathrm{v} / \mathrm{v}$ ) as an extraction solvent. Analysis was performed under a dim light to avoid chlorophyll degradation. Determining chlorophyll a and b (Chl $a$ and $\mathrm{Chl} b$ ), total chlorophyll (Chl $a+b$ ), and Chl $a / \mathrm{Chl} b$ ratio was performed according to Šesták et al. (1971), while total carotenoids ( Car $\left._{\text {total }}\right)$ were determined according to Lichtenthaler (1987). The results were expressed as $\mathrm{mg} \mathrm{g}^{-1} \mathrm{dw}$. Fully expanded adult leaves were collected for determination of photosynthetic pigments in July and September from all trees ( $n=12$ trees per treatment), frozen immediately in liquid nitrogen, and stored at $-80^{\circ} \mathrm{C}$ until analysis.

\subsection{Total soluble sugars and starch determination}

The total soluble sugars and starch concentrations in the leaves were determined using the anthrone method (Irigoyen et al., 1992), with minor modifications. In brief, for total soluble sugars extraction, the leaf discs were heated in $10 \mathrm{~mL}$ of ethanol/distilled-water $(80 / 20$, v/v) for one hour. Next, $3 \mathrm{~mL}$ of fresh anthrone was added to $200 \mu \mathrm{L}$ of each alcoholic extract, placed in a bath of boiling water for $10 \mathrm{~min}$ and left to cool. Afterwards, the absorbance values were recorded at $625 \mathrm{~nm}$. The solid fraction from the above extraction was used to determine the starch concentration. Starch extraction was performed with $30 \%$ perchloric acid (Osaki et al., 1991). The starch concentration was determined by the anthrone method described above, but with a volume of $300 \mu \mathrm{L}$ of each extract. The results were expressed as $\mathrm{mg} \mathrm{g}^{-1} \mathrm{dw}$. Fully expanded adult leaves were collected for determination of total soluble sugars and starch in July and September from all trees ( $\mathrm{n}=12$ trees per treatment), frozen immediately in liquid nitrogen, and stored at $-80^{\circ} \mathrm{C}$ until analysis.

\subsection{Soluble proteins determination}

The method of Bradford et al. (1976) was used to quantify the amount of soluble proteins. A grinding medium containing $50 \mathrm{mM}$ phosphate buffer ( $\mathrm{pH}$ 7.8), $0.1 \mathrm{mM}$ ethylenediaminetetraacetic acid (EDTA), $100 \mu \mathrm{M}$ phenylmethylsulfonyl fluoride (PMSF), and $2 \%$ polyvinylpyrrolidone (PVP) ( $\mathrm{w} / \mathrm{v}$ ) was the basis for the homogenization of leaf discs and proportion of solvent versus sample. Bovine serum albumin (BSA) (Sigma-aldrich, Tauferkirchen, Germany) was used as the standard. The results were expressed as $\mathrm{mg} \mathrm{g}^{-1} \mathrm{dw}$. Fully expanded adult leaves were collected for determination of soluble proteins in July and September from all trees ( $\mathrm{n}=12$ trees per treatment), frozen immediately in liquid nitrogen, and stored at $-80^{\circ} \mathrm{C}$ until analysis.

\subsection{Plant endogenous hormones determination}

The content of $\mathrm{ABA}$ and indole-3-acetic acid (IAA) hormones was determined according to Ergün et al. (2002), with minor modifications. 
Table 2

Relative water content (RWC; \%) values of almond trees influenced by different irrigation treatments during different dates and years. Values are means, $\mathrm{n}=12$ trees treatment group ${ }^{-1}$. Different letters indicate significant differences $(p<0.05)$.

\begin{tabular}{|c|c|c|c|c|}
\hline \multirow[t]{2}{*}{ Year } & \multirow[t]{2}{*}{ Treatment } & \multicolumn{3}{|l|}{ RWC (\%) } \\
\hline & & July & August & September \\
\hline \multirow[t]{6}{*}{2015} & T100 & 85.05 a & $84.56 \mathrm{a}$ & 90.68 a \\
\hline & T70 & $84.03 \mathrm{a}$ & $85.72 \mathrm{a}$ & $90.43 \mathrm{a}$ \\
\hline & T35 & 83.67 a & $84.27 \mathrm{a}$ & 88.42 a \\
\hline & T100-35 & $84.36 \mathrm{a}$ & $83.14 \mathrm{a}$ & $87.63 \mathrm{a}$ \\
\hline & T0 & $77.65 \mathrm{~b}$ & $74.00 \mathrm{~b}$ & $74.77 \mathrm{~b}$ \\
\hline & $p$-value & $* * *$ & $* * *$ & $* * *$ \\
\hline \multirow[t]{6}{*}{2016} & T100 & 84.84 a & 90.68 a & $89.13 \mathrm{a}$ \\
\hline & T70 & $84.11 \mathrm{a}$ & 91.98 a & $90.11 \mathrm{a}$ \\
\hline & T35 & 83.15 a & 92.37 a & 88.57 a \\
\hline & T100-35 & $84.22 \mathrm{a}$ & $90.40 \mathrm{a}$ & $84.70 \mathrm{~b}$ \\
\hline & & $69.87 \mathrm{~b}$ & $82.70 \mathrm{~b}$ & $83.40 \mathrm{~b}$ \\
\hline & $p$-value & $* * *$ & $* * *$ & $* * *$ \\
\hline
\end{tabular}

Significant at $p<0.001(* * *)$.

One hundred $\mathrm{mg}(\mathrm{dw})$ of plant material was combined with $5 \mathrm{~mL}$ of methanol/chloroform $/ 2 \mathrm{~N}$ ammonium hydroxide (12/5/3, v/v/v). Each extract was then kept at $-20^{\circ} \mathrm{C}$ until analysis. The combined extract was then treated with $4 \mathrm{~mL}$ of distilled water and the chloroform phase discarded, while the water-methanol phase evaporated. The water phase was adjusted to $\mathrm{pH} 2.5$ for ABA and IAA extractions with $1 \mathrm{~N} \mathrm{HCl}$, and $3 \mathrm{~mL}$ of ethyl acetate was added and extracted three times to obtain free-form ABA and IAA. Spectroscopic analysis was performed using wavelengths of $254 \mathrm{~nm}$ for IAA and $263 \mathrm{~nm}$ for ABA. Results were expressed as average values as $\mu \mathrm{g} \mathrm{g}^{-1} \mathrm{dw}$, using standard synthetic IAA and $\mathrm{ABA}$ as equivalents. Adult leaves were collected to determine IAA and ABA hormones on three dates of each season (22 July, 12 August and 14 September in 2015, and 28 July, 18 August and 12 September in 2016), frozen immediately in liquid nitrogen, and stored at $-80^{\circ} \mathrm{C}$ until analysis.

\subsection{Gas exchange measurements}

Leaf gas exchange measurements were performed using a portable Infrared Gas Analyzer System (IRGA) (LCpro +, Hoddesdon, England), with a $2.5 \mathrm{~cm}^{2}$ leaf chamber (ADC-PLC), operating in the open mode, at midday (13:00-14:30) on all three dates in both years, on two blocks per treatment ( $\mathrm{n}$ trees $=6$ ). IRGA is based on the fact that $\mathrm{CO}_{2}$ and $\mathrm{H}_{2} \mathrm{O}$ strongly absorb infrared radiation. Using the equations developed by von Caemmerer and Farquhar (1981) from gas exchange measurements, the net $\mathrm{CO}_{2}$ assimilation rate (A), transpiration rate (E), stomatal conductance (gs), and intercellular $\mathrm{CO}_{2}$ concentration (Ci) were estimated. In addition, intrinsic water use efficiency (iWUE $=\mathrm{A} / \mathrm{gs}$ ) was calculated.

\subsection{Yield determination}

The almonds were harvested at maturity, the hulls were immediately removed, and the yield per tree was recorded.

\subsection{Statistical analysis}

To examine behavior between treatments, the data were analyzed with a one-way analysis of variance (ANOVA), and to confirm the effect of different studied parameters (year, treatment and date), with a multifactor ANOVA (presented as Supplementary Material). For the relationship between parameters, Pearson's correlation was performed. All analyses were done using the Statgraphics 5.1 plus statistical program (Statgraphics Plus for Windows 5.1, 2005; Statistical Graphics Corporation, Rockville, Maryland, USA). Differences between the means were compared using a LSD test at $p<0.05$.

\section{Results}

\subsection{Irrigation and plant water status}

In relation to the different weather conditions during the two seasons of the study, the amounts of water applied for treatments T100, T100-35, T70 and T35 were 3259, 1931, 2173, $1086 \mathrm{~m}^{3} \mathrm{ha}^{-1}$ in 2015, and 2943, 1534, 1962, and $981 \mathrm{~m}^{3} \mathrm{ha}^{-1}$ in 2016 (Table 1).

Relative water content was during summer months of both years always significantly lower in non-irrigated trees compared to all other treatments (Table 2), while regarding the predawn leaf water potential, all deficit irrigation treatments showed values lower than T100 throughout the growing season (data not shown). More specifically, throughout the experiment in 2015, T100 had predawn leaf water potential values that varied in range $-0,47$ to $-0,70 \mathrm{MPa}$ which were close to those found by Egea et al. (2010) for well-watered almond trees, and in 2016, T100 had stem water potential values that varied in range $-0,95$ to $-1,30 \mathrm{MPa}$, which were also similar to those found by Fuentes et al. (2013) and Egea et al. (2013) for well-watered almond trees. These results indicated that T100 was a well-watered control treatment.

\subsection{Photosynthetic pigment behavior under deficit irrigation strategies in almond leaves}

The behavior of photosynthetic pigment parameters influenced by different treatments, years and dates are presented in Fig. 2. According to these results, statistically significant differences between treatments were observed for total chlorophyll and carotenoid contents in September 2015, with T100-35 displaying the highest values for both parameters ( 3.39 and $0.62 \mathrm{mg} \mathrm{g}^{-1} \mathrm{dw}$, respectively), while the non-irrigated trees (2.76 and $0.52 \mathrm{mg} \mathrm{g}^{-1} \mathrm{dw}$, respectively) and T35 (2.02 and $0.44 \mathrm{mg} \mathrm{g}^{-1} \mathrm{dw}$, respectively) showed the lowest (Fig. 2). The ratio $\mathrm{Chl} a / \mathrm{Chl} b$ was significantly affected by the irrigation treatment in July 2015 and September 2016, T100 displaying the highest values $(2.87$ and 2.90 , respectively), while T0 the lowest (2.64 and 2.58, respectively). Similar trend was observed for the $\mathrm{Chl}_{\text {total }} / \mathrm{Car}_{\text {total }}$ ratio throughout the seasons.

Furthermore, when comparing dates, photosynthetic pigment contents (total chlorophyll and carotenoids) were significantly higher ( $p<0.001$ ) in July (4.13 and $0.70 \mathrm{mg} \mathrm{g}^{-1} \mathrm{dw}$, respectively) compared to September ( 3.29 and $0.59 \mathrm{mg} \mathrm{g}^{-1} \mathrm{dw}$, respectively), while the values observed in 2015 ( 2.98 and $0.54 \mathrm{mg} \mathrm{g}^{-1} \mathrm{dw}$, respectively) were significantly lower $(p<0.001)$ than in 2016 (4.44 and $0.75 \mathrm{mg} \mathrm{g}^{-1} \mathrm{dw}$, respectively), by $33 \%$ on average (Supplementary Material 1 ). 

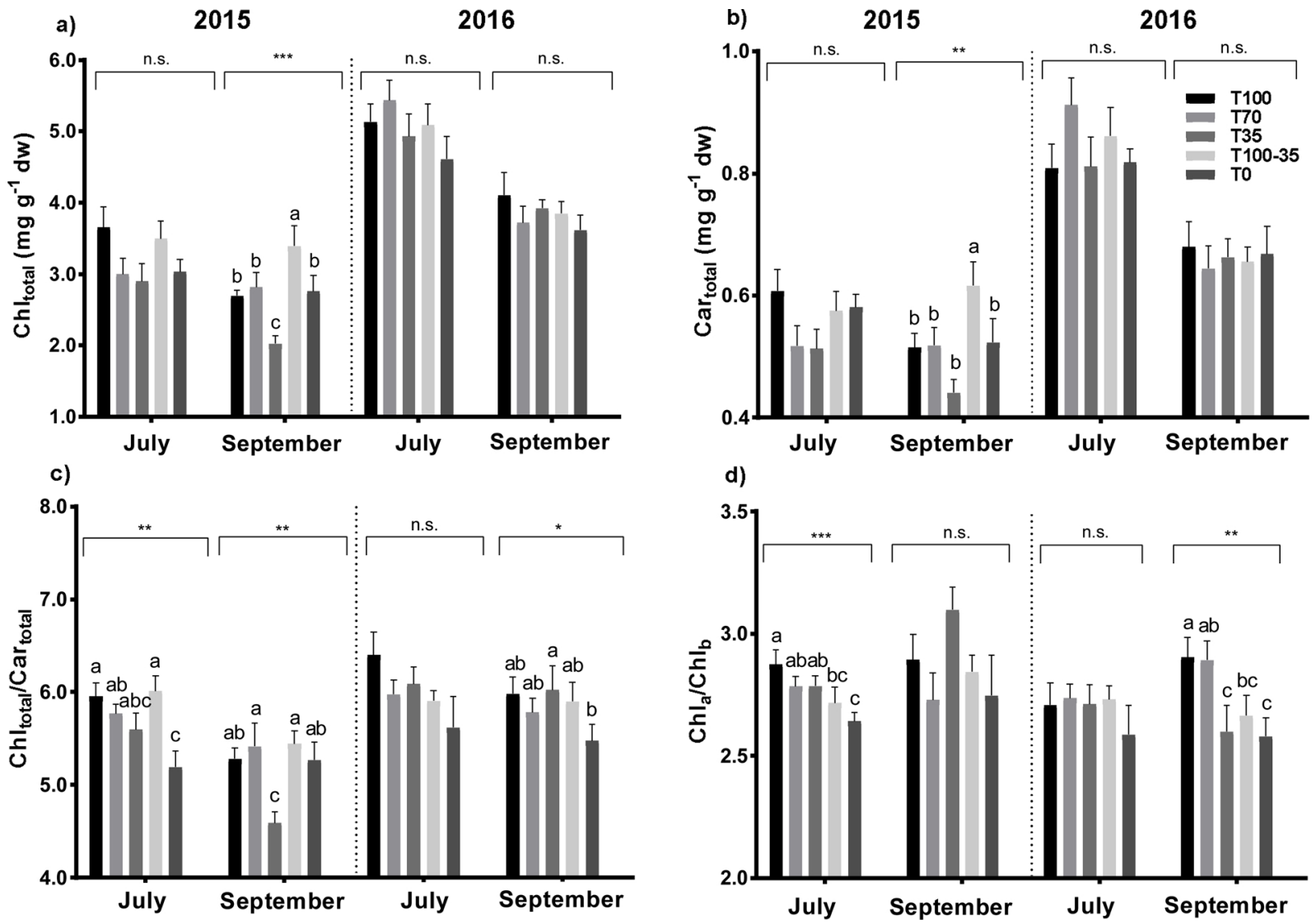

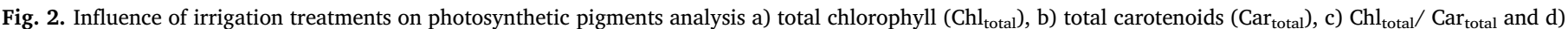

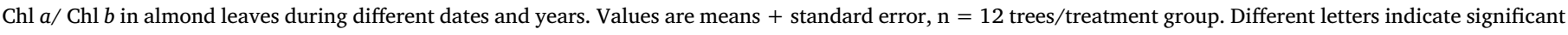
differences $(p<0.05)$. Significance: ${ }^{* *} p<0.001,{ }^{* *} p<0.01,{ }^{*} p<0.05$, n.s. no significant differences.

\subsection{Influence of deficit irrigation strategies on total soluble sugars, starch and soluble proteins in almond leaves}

Soluble protein content significantly differed among treatments in September 2016, where T0 displayed the highest content $\left(25.89 \mathrm{mg} \mathrm{g}^{-1}\right.$ $\mathrm{dw}$ ) compared to all the other treatments (ranging from 13.03-17.48 $\mathrm{mg} \mathrm{g}^{-1} \mathrm{dw}$ ). The starch content was significantly different between the treatments in September 2015 and July 2016 in the present study; leaves from T70 trees have shown the highest starch content compared to other treatments in September 2015, while the values recorded from the leaves of non-irrigated trees $\left(51.62 \mathrm{mg} \mathrm{g}^{-1} \mathrm{dw}\right)$ were statistically lower compared to the two sustained deficit irrigation treatments (T35 and T70) and all the irrigated treatments in July 2016 (Fig. 3). Significant differences among treatments were notified in September 2015, and non-irrigated trees had the highest accumulated leaf total soluble sugars (76.67 $\mathrm{mg} \mathrm{g}^{-1} \mathrm{dw}$ ) (Fig. 3).

In general, in July, the trees displayed overall significantly higher totals of soluble sugars $(p<0.01)$ and soluble proteins $(p<0.001)$ (63.07 and $27.76 \mathrm{mg} \mathrm{g}^{-1} \mathrm{dw}$, respectively) compared to September (59.49 and $16.01 \mathrm{mg} \mathrm{g}^{-1} \mathrm{dw}$, respectively), while for starch, the trend was the opposite, with significantly higher values in September (93.60 $\left.\mathrm{mg} \mathrm{g}^{-1} \mathrm{dw}\right)$ than in July $\left(69.47 \mathrm{mgg}^{-1} \mathrm{dw}\right)(p<0.001)$ (Supplementary Material 2). Significant differences for soluble protein and starch contents were also observed between the years, when the values recorded in 2015 (16.17 and $73.02 \mathrm{mg} \mathrm{g}^{-1} \mathrm{dw}$, respectively) were significantly lower than in 2016 (27.59 and $90.06 \mathrm{mg} \mathrm{g}^{-1} \mathrm{dw}$, respectively). Regarding total soluble sugars, there was better performance in $2015\left(65.81 \mathrm{mg} \mathrm{g}^{-1} \mathrm{dw}\right)$ compared to $2016\left(54.76 \mathrm{mg} \mathrm{g}^{-1}\right.$ dw) $(p<0.001)$ (Supplementary Material 2).

\subsection{Plant hormone responses to deficit irrigation strategies in almond leaves}

The results revealed that IAA was more synthesized in 2015 $\left(0.74 \mu \mathrm{g} \mathrm{g}^{-1} \mathrm{dw}\right)$ than in $2016\left(0.70 \mu \mathrm{g} \mathrm{g}^{-1} \mathrm{dw}\right)$, while the behavior of
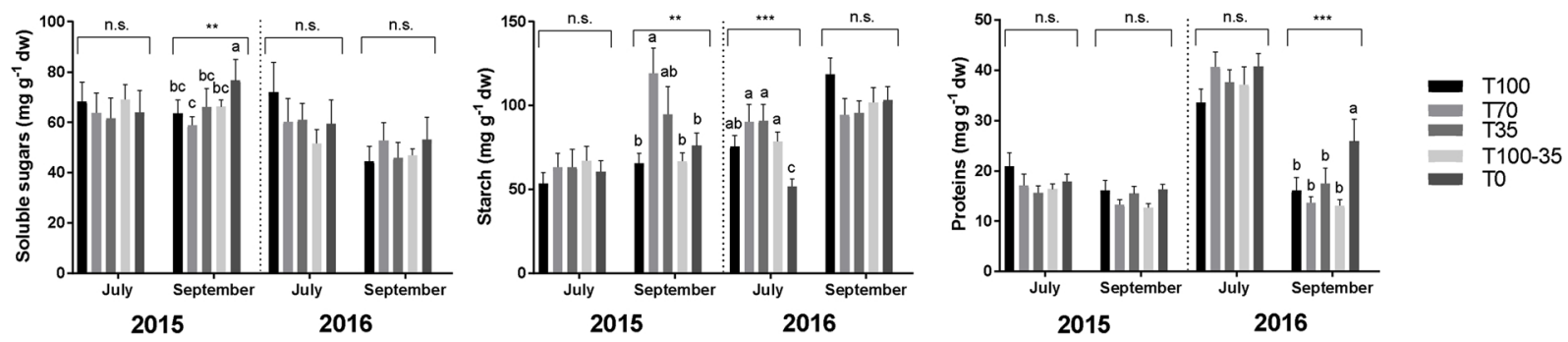

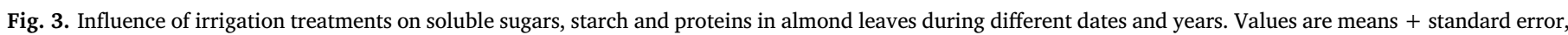

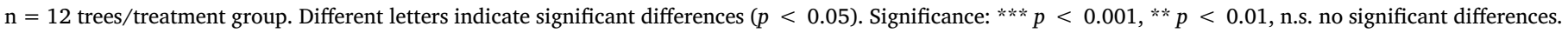


2015

a)

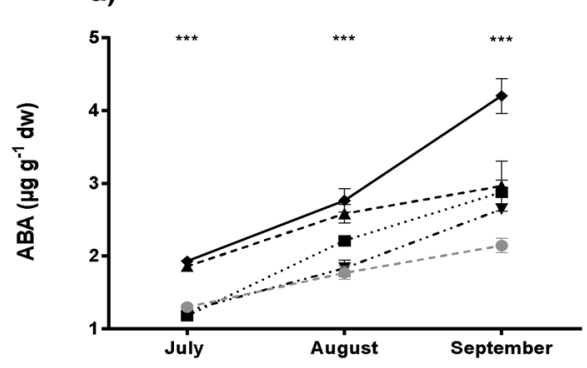

c)

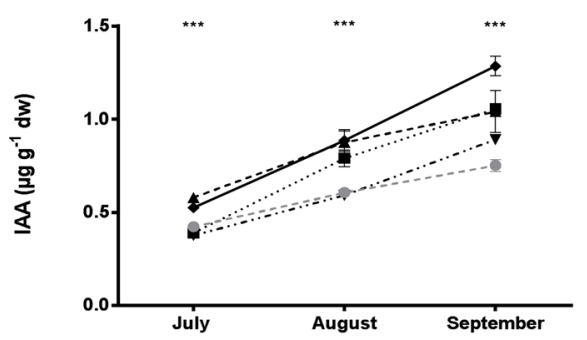

2016

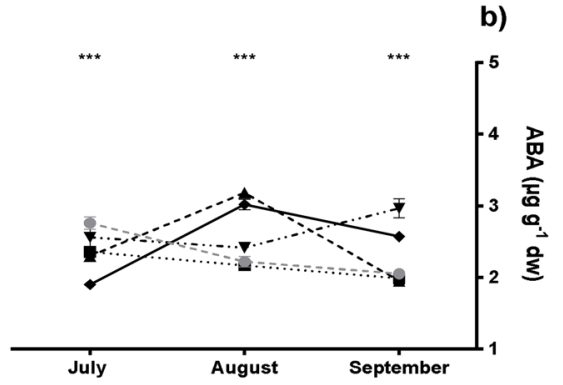

d)

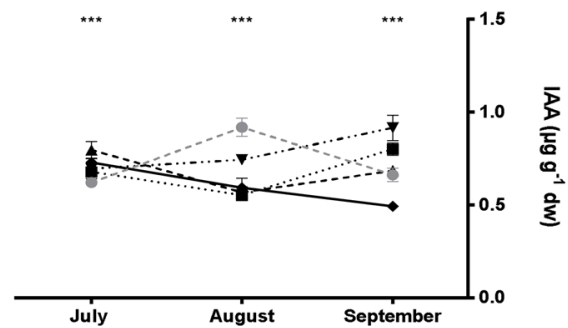

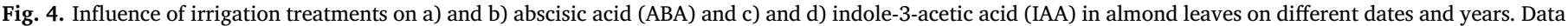
represent the mean \pm standard error. Significance: ${ }^{* * *} p<0.001$.

ABA was just the opposite (2.23 and $2.43 \mu \mathrm{g} \mathrm{g}^{-1} \mathrm{dw}$ in 2015 and 2016, respectively) ( $p<0.001$ ) (Supplementary Material 3). Simple main effects analysis showed that in September plants accumulated more IAA compared to August followed by July, while for the ABA the significant difference was observed for August and September, displaying higher values compared with July. Plants without irrigation showed significantly higher accumulation of both hormones compared to the irrigated ones, in specific to the T100 in 2015, while in 2016 the tendency of hormone accumulation depended on the month (Fig. 4). T35 and T0 displayed statistically higher values compared to T100 and T100-35 for both IAA and ABA (Supplementary Material 3).

\subsection{Gas exchange in almond trees under deficit irrigation strategies}

Non-irrigated trees showed significantly lower values of gs (0.027$0.034 \mathrm{~mol} \mathrm{H}_{2} \mathrm{O} \mathrm{m}^{-2} \mathrm{~s}^{-1}$, on average) compared to the other four treatments (ranging from 1.05 to $1.30 \mathrm{~mol} \mathrm{H}_{2} \mathrm{O} \mathrm{m}^{-2} \mathrm{~s}^{-1}$, on average), with closed stomata leading to lower values in photosynthetic (A) and transpiration rates (E) in T0 $\left(2.40-2.57 \mu \mathrm{mol} \mathrm{m}^{-2} \mathrm{~s}^{-1}\right.$ and 1.29$1.76 \mathrm{mmol} \mathrm{m}^{-2} \mathrm{~s}^{-1}$ on average, respectively), compared to other treatments (ranging 8.27-9.14 $\mu \mathrm{mol} \mathrm{m}^{-2} \mathrm{~s}^{-1}$ and 4.15$4.62 \mathrm{~m} \mathrm{~mol} \mathrm{~m}^{-2} \mathrm{~s}^{-1}$, on average, respectively) (Fig. 6). The intercellular $\mathrm{CO}_{2}$ concentration (Ci) in September displayed lower overall values $\left(214.97 \mu \mathrm{mol} \mathrm{mol}^{-1}\right.$, on average) compared to the first two months studied (on average 234.81 and $236.54 \mu \mathrm{mol} \mathrm{mol}^{-1}$ in July and August, respectively), in specific for T0 significantly decreasing in the Septembers of both seasons (Fig. 6). Intrinsic water use efficiency (iWUE) increased significantly as the water supplied to plants decreased, so that the T0 treatment showed the highest values $\left(82.41 \mu \mathrm{mol} \mathrm{mol}^{-1}\right.$, on average).

Regarding correlations, a close correlation was observed between A and $\mathrm{gs}(\mathrm{r}=0.903, p<0.001)$ and $\mathrm{A}$ and $\mathrm{E}(\mathrm{r}=0.769, p<0.001)$, and it was possible to observe a strong negative correlation between $\mathrm{Ci}$ and $\mathrm{A} / \mathrm{gs}(\mathrm{r}=-0.973, p<0.001)$.
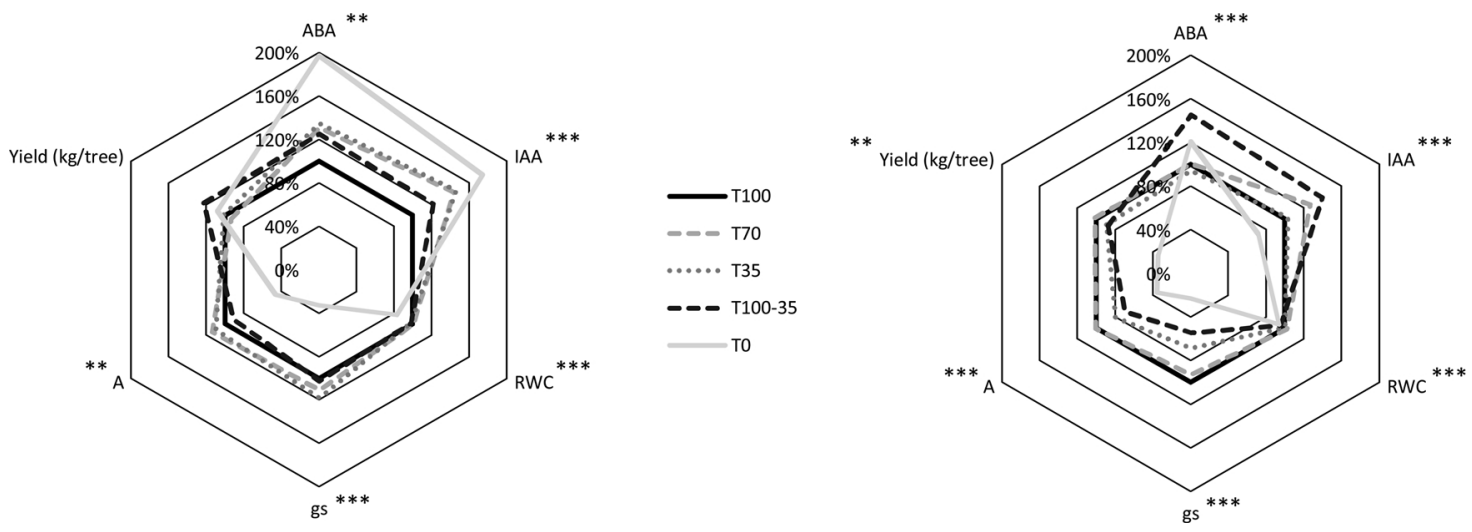

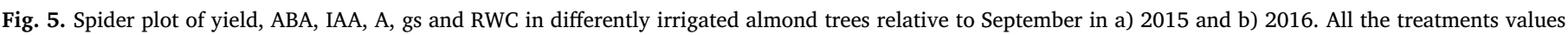

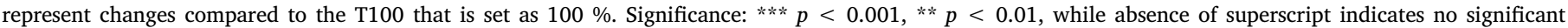
differences. 
a)

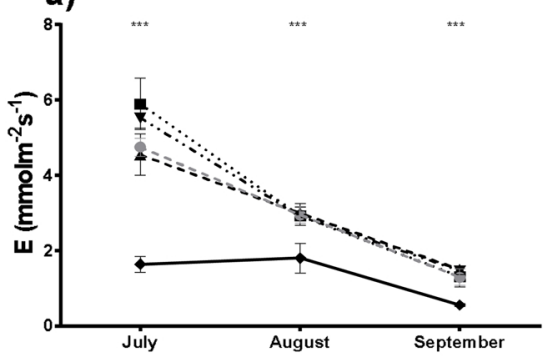

c)

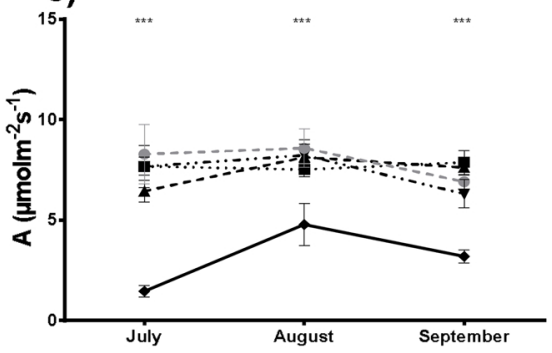

e)

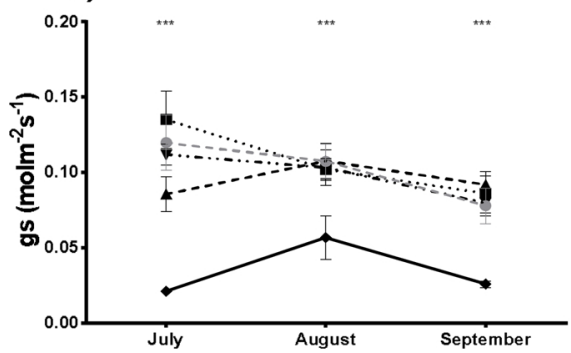

g)

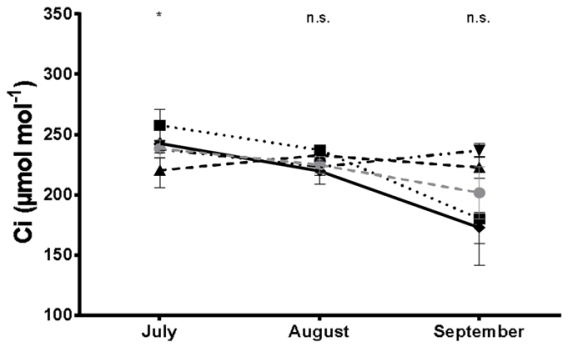

i)

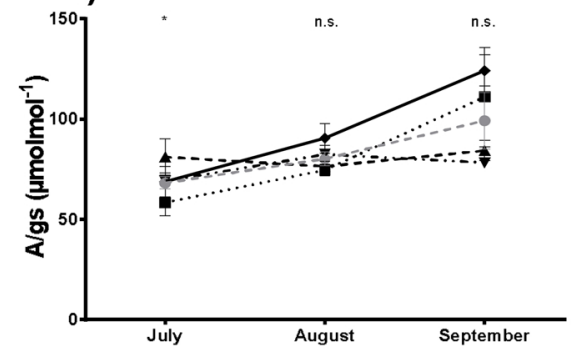

b)

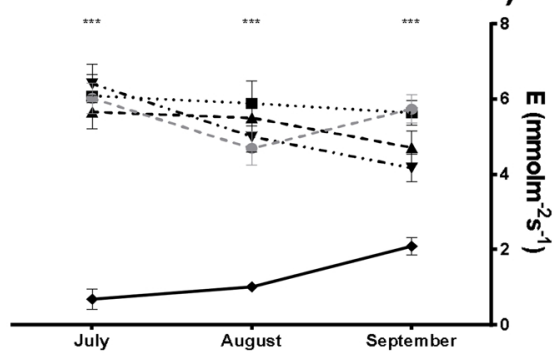

d)

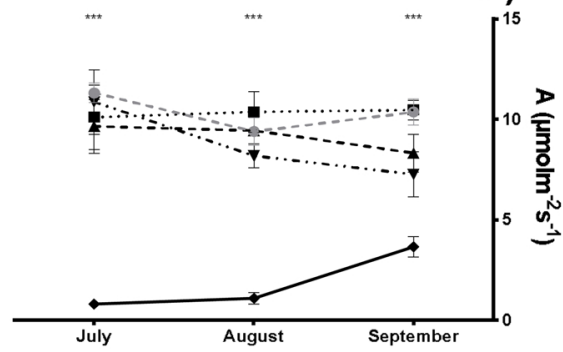

f)

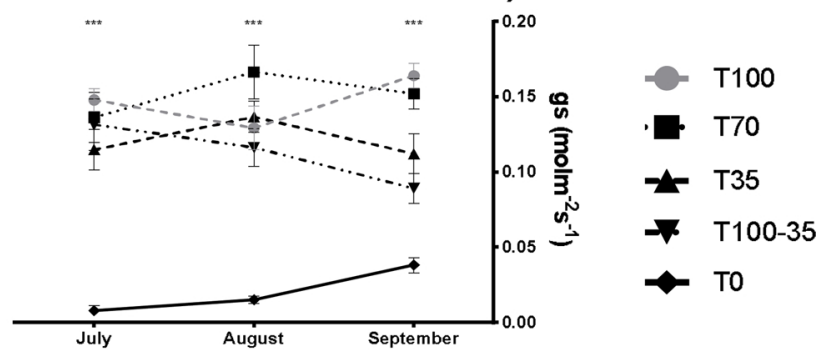

h)

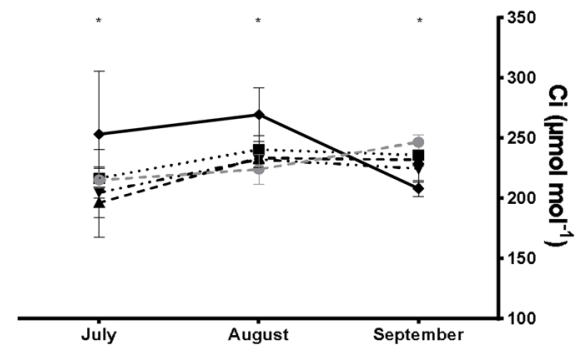

j)

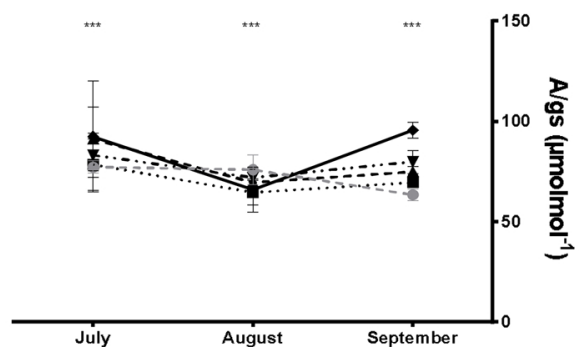

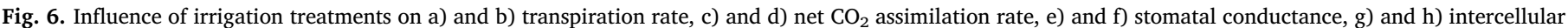

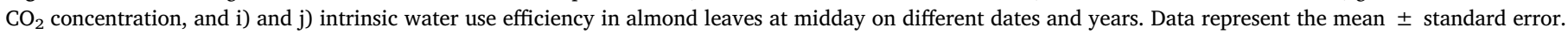
Significance: ${ }^{* * *} p<0.001,{ }^{*} p<0.05$, n.s. no significant differences.

\subsection{Effect of deficit irrigation strategies on almond tree yield}

Yield was significantly lower in 2016 (2.63 $\mathrm{kg}$ tree $\left.^{-1}\right)$ compared to $2015\left(9.19 \mathrm{~kg} \mathrm{tree}^{-1}\right)$. In 2015, trees under water deficit treatments and even non-irrigated ones showed higher yields compared to optimally irrigated trees (T100). On the other hand, in 2016, T100 showed significantly higher values compared to non-irrigated trees, where the decrease of around $67 \%$ was more accentuated (Fig. 5). 


\section{Discussion}

\subsection{Photosynthetic pigment behavior under deficit irrigation strategies in almond leaves}

The photosynthetic pigments in leaves under stress are reduced, and results in the present study are partially in agreement with that, as nonirrigated trees, as well as trees under the deficit irrigation treatment T35, displayed the lowest values. This probably happens due to pigment photo-oxidation and chlorophyll degradation, or to stress-induced impairment in pigment biosynthetic pathways (Ashraf and Harris, 2013). Any decrease during drought implies a reduced capacity for light harvesting and depends on the duration and intensity of the stress. However, it seems that the water stress does not affect almond tree leaves on the pigment level, as the leaves from the fully irrigated trees were not significantly different compared to that from deficit irrigation treatments and non-irrigated trees. Higher values in the present study in July compared to September were expected, as September marks the onset of leaf senescence, when degradation of pigments already occurs (Bertrand and Schoefs, 1999). The Chl $a$ content in the present study varied, probably due to degradation or lower biosynthesis in plants receiving less water, while the $\mathrm{Chl} b$ did not follow the same trend. Chl $a$ has been stated to be more sensitive to photo-oxidation than Chl $b$ (Bertrand and Schoefs, 1999), consequently, the ratio $\mathrm{Chl} a / \mathrm{Chl} b$ shows higher values for treatments with higher $\mathrm{Chl} a$. This ratio in the present study (Fig. 2) was within the reported values for leaves of different species, ranging from 2:1 to 4:1 (Filimon et al., 2016; Kitajima and Hogan, 2003), and is a sign of functional pigment equipment and photosynthetic apparatus light adaptation (Lichtenthaler and Buschmann, 2005). Although it has been observed in different species that the $\mathrm{Chl} a / \mathrm{Chl} b$ ratio normally increases with water stress, as the enzymatic reduction of Chl $b$ to Chl $a$ is a crucial early step in Chl breakdown (Hörtensteiner and Kräutler, 2011), this was not the case in this study. Fully irrigated plants showed the highest ratio, this decreasing with less water applied to the non-irrigated plants in general showing the lowest ratio, as reported by Karimi et al. (2013) who obtained similar results when comparing different almond varieties and found a higher $\mathrm{Chl} a / \mathrm{Chl} b$ ratio in the leaves of drought tolerant varieties.

Even though the non-irrigated trees displayed lower values than all the irrigated treatments regarding the ratio between total chlorophyll content and carotenoids (Fig. 2), in this study presented values were not as low as $2.5-3.5$, but ranged from $5.2-5.9$, which may be a sign that stress was not severe not even for the non-irrigated trees, or may confirm the almond tree as a drought tolerant species. This ratio is an indicator of the greenness of the plants; lower values are a sign of stress and damage to the plant and its photosynthetic apparatus. It is seen in the faster breakdown of chlorophylls compared to carotenoids, since the latter display less sensitivity to water stress and autumnal senescence compared to chlorophylls (Bertrand and Schoefs, 1999; Lisar et al., 2012), or the capacity of higher carotenoid content to protect the photosynthetic apparatus (Lichtenthaler and Buschmann, 2005).

\subsection{Influence of deficit irrigation strategies on total soluble sugars, starch and soluble proteins in almond leaves}

The present experiment showed significant differences between treatments only for September 2016, when non-irrigated trees (T0) displayed significantly higher values of total soluble proteins compared to the other four treatments. This probably occurred due to the greater synthesis of some stress-induced proteins in order to adjust osmotic potential and ensure the normal functioning of plant physiological processes (Fig. 3). Stress affects protein metabolism differently, by synthetizing new stress-induced proteins or degrading existing ones (Dubey, 1999). Most studies (for different species under diverse types of stress) have reported a decline in total soluble protein levels in leaves
(Sorkheh et al., 2012), mostly due to the translocation of soluble $\mathrm{N}$ products from the leaves and/or decreased synthesis. However, as in the present study, there are references stating that soluble protein content in leaves under drought conditions increases compared to normal water management treatments (Li et al., 2010).

On the other side, high ABA concentration accumulating around guard cells is known to result in stomatal closure and water conservation (Lisar et al., 2012), and also induces starch degradation upon osmotic stress (Thalmann et al., 2016). Results recorded herein are in agreement with it, as the values from the leaves of non-irrigated trees on starch content were in general lower compared to irrigated treatments. Starch degradation usually happens daily, accumulating gradually during the day and degrading during the night for energy production, when photosynthesis does not occur (Thalmann et al., 2016). Furthermore, under challenging conditions, such as drought and extreme temperatures, plants generally remobilize starch to supply energy and carbon in moments when the photosynthesis might be limited (Thalmann and Santelia, 2017). Here, under conditions of water shortage, starch degradation was more accentuated compared to irrigated plants, where the degradation of starch in response to abiotic stress has been correlated with improved plant tolerance to stress (Thalmann and Santelia, 2017).

In contrast to starch synthesis, in the present study non-irrigated trees accumulated more leaf total soluble sugars, as plants under abiotic stress accumulate soluble sugars as an osmotic adjustment mechanism, regulating cells to improve water absorption and maintain cell turgor (Mohammadkhani and Heidari, 2008). The role of sugars lies not only in producing energy and synthesizing other compounds, but also in stabilizing cellular membranes (Mohammadkhani and Heidari, 2008), which is a critical factor in overall tree performance.

Furthermore, regarding monthly variations from July to September observed in the present study in soluble sugars and starch, generally in July the starch content was lower and soluble sugars content was higher compared to that obtained in September. During the active growing season (June-August) the photosynthate produced by leaves is not stored but is mobilized and transported as sucrose to various sinks for growth and metabolism, while from the mid-August to September the reduction in sink strength and allocation to the storage is more present (Wong et al., 2003).

\subsection{Plant hormone responses to deficit irrigation strategies in almond leaves}

Plant hormones play an important role in many development processes. The key function of ABA seems to be related to regulating water equilibrium in plants and osmotic stress tolerance (Tuteja, 2007). Nonirrigated trees in the present study in general produced significantly more ABA stress hormone compared to all other treatments, and interestingly, a similar pattern was observed in the synthesis of IAA (Fig. 4). The tendency was for both hormones to increase throughout the summer. In September, non-irrigated trees (T0) displayed a significantly higher accumulation of ABA compared to the T100, of around $97 \%$ and $21 \%$ more in 2015 and 2016, respectively (Fig. 5). Indeed, abscisic acid content increases in plants with water deprivation (Vishwakarma et al., 2017). In contrast to ABA, the role of IAA under abiotic stresses is still not completely understood. In 2015, an increase of around $75 \%$ was noticed, while in 2016 , a decrease of around $30 \%$ was observed in T0 compared to T100 (Fig. 5). In this regard, there have been reports on its accumulation in stressed plants (De Diego et al., 2013) and on the involvement of defense responses during plant adaptation to drought (Rauf and Sadaqat, 2007). This may be directly related to RWC, as in September 2015, there was significant difference between treatments, with a decrease compared to T100 of around $17 \%$ for non-irrigated treatment (Fig. 5), while in September 2016, it was around $6 \%$. 


\subsection{Gas exchange in almond trees under deficit irrigation strategies}

Stomatal conductance (gs), as the earliest response to stress, is a principal limitation in mild and moderate drought (Flexas and Medrano, 2002). Values of gs below $0.05 \mathrm{~mol} \mathrm{H}_{2} \mathrm{O} \mathrm{m}^{-2} \mathrm{~s}^{-1}$ (as in the present study for non-irrigated trees during both years and throughout the summer months) are clear evidence that these trees were under severe stress (Flexas et al., 2012), and RWC values were always significantly lower in this treatment (Table 2), while differences among other treatments were mostly depended on the date and year In addition, stomatal closure decreased the local intercellular $\mathrm{CO}_{2}$ concentration and probably inhibited photosynthesis ( $\mathrm{Yu}$ et al., 2009). As the photosynthetic rate is considered a potential physiological criterion for stress tolerance (Ashraf, 2004) it is genetically dependent and strongly correlated with $\mathrm{E}$ and gs, what was noticed also in the present study. In addition to the correlation $\mathrm{A}$ and $\mathrm{E}$ in this study, the closest relationship was observed between A and gs, indicating that stomatal closure may be the main limitation to photosynthesis in almond trees. Several authors have reported a similar pattern for this fruit species, that is, decrease of A and gs with increasing water stress (Romero and Botía, 2006; Rouhi et al., 2007), as a common feature of drought-adapted species. This correlation in the present study was probably a result of variations in $\mathrm{A}$, which are strongly dependent on variations of gs caused by stomatal adjustment (Romero et al., 2004). In this study, Ci for nonirrigated trees decreased significantly in the Septembers of both seasons compared to the first two months studied. Rouhi et al. (2007) observed similar behavior in almond trees, where A and gs decreased substantially in response to increased drought stress, while Ci decreased only slightly. Parameter A in the present study was higher in all plants that received water compared to non-irrigated ones, while the tendency was the same regarding E. Full irrigation treatment caused an increase in A of about $280 \%$ at midday, compared to rainfed treatment, similarly to Gomes-Laranjo et al. (2006), who observed an increase of about $300 \%$ in the photosynthetic rate for the same variety in similar conditions (Northern Portugal). Karimi et al. (2015) reported a reduced photosynthetic rate in the 'Ferragnès' almond variety under drought conditions. Therefore, the first stage of water stress was probably due to decreased gs, and subsequently it possibly leads to heat accumulation and cell damage. At the end of the summer, non-irrigated trees herein started to lose leaves much earlier compared to other treatments, most likely as an avoidance strategy to reduce canopy size and consequently the transpiration.

Values of iWUE increased in the present study as the summer progressed. Romero and Botía (2006) reported a similar range of values as herein, where almond trees under severe drought stress displayed values between $80-96 \mu \mathrm{mol} \mathrm{CO} \mathrm{CO}_{2} \mathrm{~mol} \mathrm{H}_{2} \mathrm{O}^{-1}$. This curved assimilation behavior makes the $\mathrm{A} / \mathrm{g}_{\mathrm{s}}$ ratio increase as stomata close (Spinelli et al., 2016). As expected, a strong negative relationship was observed between $\mathrm{Ci}$ and iWUE, as the $\mathrm{A} / \mathrm{gs}$ ratio depends on intercellular leaf and partial ambient $\mathrm{CO}_{2}$ pressure $(\mathrm{Ci} / \mathrm{Ca}$ ) (Barbour et al., 2011), the latter representing an integrative parameter of iWUE.

\subsection{Effect of deficit irrigation strategies on almond tree yield}

The differences regarding yield among seasons in this study may mostly relate to the huge reduction in yield that occurred in 2016, due to high precipitation in the first five months of the year, influencing overall flower pollination, and consequently, yield. In 2016, this led to an almond average yield reduction in Portugal of $17.3 \%$ compared to 2015, while northern Portugal in particular experienced a decrease of 27.8\% (Instituto Nacional de Estatística, 2017). Fruit yield is a function of the number of fruits on a tree, and fruit weight and fruit bearing greatly depend on various factors, such as climate conditions, available water, pruning, and tree size, among others (Jiménez and Díaz, 2003). It could be assumed that in 2015, where trees under water deficit treatments and even non-irrigated ones had higher yields compared to the T100, the partitioning of assimilated carbon in almond trees favored fruit growth rather than vegetative growth. This may be a problem in young trees, where vegetative growth is most important, however, in mature almond trees (as in the present study), the results underline the suitability of this crop in terms of deficit irrigation strategies. On the other hand, in 2016, when trees were subjected to additional stress (low pollination and flower fall due to heavy rains and low temperatures during first five months of the year), irrigation proved to be critical, leading to a yield increase of around $180 \%$ compared to non-irrigated trees.

Finally, as the optimum irrigation condition in this study could be highlighted the regulated deficit irrigation regime $\mathrm{T} 100-35$, in areas and years when water is limited, as it does not lead to yield losses, while the plant status remains unstressed and the water saving compared to the T100 was of about $44 \%$ average in two studied years. However, as with most Mediterranean fruit trees, in order to obtain the maximum crop potential, in years and areas where water is not restricted, full irrigation has demonstrated to boost the best performance.

\section{Conclusions}

Stomatal conductance, photosynthetic and transpiration rates, total photosynthetic pigments, total soluble sugars, starch and soluble proteins, and hormone synthesis showed that the physiology of almond trees was affected by water stress created by the application of several deficit irrigation treatments in two consecutive years, ultimately affecting yield. However, even when under stress, almond tree performance was not affected by severe stress, though this was accentuated in terms of gas exchange parameters, and stomatal closure was probably the main limitation to photosynthesis. The almond tree has been confirmed to be a drought tolerant species, since when water is scarce, reducing the water application to $35 \%$ ETc during fruit filling stage, does not lead to yield losses, while the plant status remains unstressed and water saving is substantial compared to the full irrigation. However, as with most Mediterranean fruit trees, in order to obtain the maximum crop potential in years and areas where water is not restricted, full irrigation has been demonstration to boost best performance.

\section{Declaration of Competing Interest}

The authors declare that they have no known competing financial interests or personal relationships that could have appeared to influence the work reported in this paper.

\section{Acknowledgments}

IP acknowledges the financial support provided by the FCTPortuguese Foundation for Science and Technology (SFRH/BD/52539/ 2014), under the Doctoral Programme "Agricultural Production Chains - from fork to farm" (PD/00122/2012). This work was also supported by National Funds by FCT - Portuguese Foundation for Science and Technology, under the project UID/AGR/04033/2019 and by the project PRODER "Estratégias Integradas para o aumento da produtividade da amendoeira em Trás-os-Montes, $n^{\circ}$ 54611. 2014 a 2018. The authors wish to acknowledge the help and support provided during field and laboratory work by Ana Monteiro, Cristiana Teixeira, Helena Ferreira, Ivo Oliveira, Linton Dinis, Sara Bernardo, Silvia Afonso, and Silvina Morais, and thank João Santos and Chenyao Yang for help with climate data.

\section{Appendix A. Supplementary data}

Supplementary material related to this article can be found, in the online version, at doi:https://doi.org/10.1016/j.scienta.2019.108990. 


\section{References}

Allen, R.G., Pereira, L.S., Raes, D., Smith, M., 1998. Crop Evapotranspiration — guidelines for Computing Crop Water Requirements. FAO Irrigation and drainage paper 56. Food and Agriculture Organization, Rome.

Ashraf, M., 2004. Some important physiological selection criteria for salt tolerance in plants. Flora 199, 361-376. https://doi.org/10.1078/0367-2530-00165.

Ashraf, M., Harris, P.J.C., 2013. Photosynthesis under stressful environments: an overview. Photosynthetica 51, 163-190. https://doi.org/10.1007/s11099-013-0021-6.

Barbour, M.M., Tcherkez, G., Bickford, C.P., Mauve, C., Lamothe, M., Sinton, S., Brown, $\mathrm{H}$., 2011. $\delta 13 \mathrm{C}$ of leaf-respired $\mathrm{CO}_{2}$ reflects intrinsic water-use efficiency in barley. Plant Cell Environ. 34, 792-799. https://doi.org/10.1111/j.1365-3040.2011. 02282.x.

Bertrand, M., Schoefs, B., 1999. Photosynthetic pigment metabolism in plants during stress. Handbook of Plant and Crop Stress. Marcel Dekker, Inc., New York, USA, pp. 527-544.

Bradford, M.M., Dong, Y., Xu, L., Liu, S., Bai, X., Bradford, M., et al., 1976. A rapid and sensitive method for the quantitation of microgram quantities of protein utilizing the principle of protein-dye binding. Anal. Biochem. 72, 248-254. https://doi.org/10. 1016/0003-2697(76)90527-3.

De Diego, N., Rodríguez, J.L., Dodd, I.C., Pérez-Alfocea, F., Moncaleán, P., Lacuesta, M., 2013. Immunolocalization of IAA and ABA in roots and needles of radiata pine (Pinus radiata) during drought and rewatering. Tree Physiol. 33, 537-549. https://doi.org/ 10.1093/treephys/tpt033.

Dubey, R.S., 1999. Protein synthesis by plants under stressful conditions. In: Pessarakli, M. (Ed.), Handbook of Plant and Crop Stress 2. Marcel Dekker, Inc., New York, USA, pp. 365-397.

Egea, G., González-Real, M.M., Baille, A., Nortes, P.A., Sánchez-Bel, P., Domingo, R., 2009. The effects of contrasted deficit irrigation strategies on the fruit growth and kernel quality of mature almond trees. Agric. Water Manag. 96, 1605-1614. https:// doi.org/10.1016/j.agwat.2009.06.017.

Egea, G., Nortes, P.A., Domingo, R., Baille, A., Pérez-Pastor, A., González-Real, M.M., 2013. Almond agronomic response to long-term deficit irrigation applied since orchard establishment. Irrig. Sci. 31 (3), 445-454. https://doi.org/10.1007/s00271 012-0322-8.

Egea, G., Nortes, P.A., González-Real, M.M., Baille, A., Domingo, R., 2010. Agronomic response and water productivity of almond trees under contrasted deficit irrigation regimes. Agric. Water Manag. 97, 171-181. https://doi.org/10.1016/j.agwat.2009. 09.006.

English, M., 1990. Deficit irrigation. I: analytical framework. J. Irrig. Drain. Eng. 116 (3), 399-412. https://doi.org/10.1061/(ASCE)0733-9437(1990)116:3(399).

Ergün, N., Topcuoglu, S., Yildiz, A., 2002. Auxin (indole-3-acetic acid), gibberellic acid (GA 3), abscisic acid (ABA) and cytokinin (zeatin) production by some species of mosses and lichens. Turk. J. Botany 26, 13-18.

European Parliament and the Council of the European Union, 2000. Directive 2000/60/ EC of the European Parliament and of the Council of 23 October 2000 establishing a framework for Community action in the field of water policy. Off. J. Eur. Communities: Legis., L327 1-72.

Faroog, M., Wahid, A., Kobayashi, N., Fujita, D., Basra, S.M.A., 2009. Plant drought stress: effects, mechanisms and management. Sustainable Agriculture. Springer, Dordrecht, pp. 153-188.

Ferreres, E., Goldfein, R.E., Pruitt, W.O., Hendersen, D.W., Hogan, R.M., 1981. The irrigation management program: a new approach to computer assisted irrigation scheduling. Proc. Am. Soc. Agric. Eng. Irrig. Sch. Conf. 202.

Filimon, R.V., Rotaru, L., Filimon, R.M., 2016. Quantitative investigation of leaf photosynthetic pigments during annual biological cycle of Vitis vinifera L. Table grape cultivars. S. Afr. J. Enol. Vitic. 37, 1-14. https://doi.org/10.21548/37-1-753.

Flexas, J., Gallé, A., Galmés, J., Ribas-Carbo, M., Hipólito, M., 2012. The response of photosynthesis to soil water stress. In: Aroca, R. (Ed.), Plant Responses to Drought Stress. From Morphological to Molecular Features. Springer-Verlag, pp. 129-144.

Flexas, J., Medrano, H., 2002. Drought-inhibition of photosynthesis in C3plants: stomatal and non-stomatal limitations revisited. Ann. Bot. 89, 183-189. https://doi.org/10. 1093/aob/mcf027.

Fuentes, S., Mahadevan, M., Bonada, M., Skewes, M.A., Cox, J.W., 2013. Night-time sap flow is parabolically linked to midday water potential for field-grown almond trees. Irrig. Sci. 31 (6), 1265-1276. https://doi.org/10.1007/s00271-013-0403-3.

Girona, J., Mata, M., Marsal, J., 2005. Regulated deficit irrigation during the kernel-filling period and optimal irrigation rates in almond. Agric. Water Manag. 75, 152-167. https://doi.org/10.1016/j.agwat.2004.12.008.

Goldhamer, D.A., Viveros, M., 2000. Effects of preharvest irrigation cutoff durations and postharvest water deprivation on almond tree performance. Irrig. Sci. 19 (3), 125-131. https://doi.org/10.1007/s002710000013.

Goldhamer, D.A., Viveros, M., Salinas, M., 2006. Regulated deficit irrigation in almonds: effects of variations in applied water and stress timing on yield and yield components. Irrig. Sci. 24 (2), 101-114. https://doi.org/10.1007/s00271-005-0014-8.

Gomes-Laranjo, J., Coutinho, J.P., Galhano, V., Cordeiro, V., 2006. Responses of five almond cultivars to irrigation: photosynthesis and leaf water potential. Agric. Water Manag. 83, 261-265. https://doi.org/10.1016/j.agwat.2005.11.007.

Haylock, M.R., Hofstra, N., Klein Tank, A.M.G., Klok, E.J., Jones, P.D., New, M., 2008. A European daily high-resolution gridded data set of surface temperature and precipitation for 1950-2006. J. Geophys. Res. Atmos. 113. https://doi.org/10.1029/ 2008JD010201.

Hörtensteiner, S., Kräutler, B., 2011. Chlorophyll breakdown in higher plants. Biochim. Biophys. Acta - Bioenerg. https://doi.org/10.1016/j.bbabio.2010.12.007.

Instituto Nacional de Estatística, 2017. Estatísticas Agrícolas 2016. Lisboa, Portugal.

Irigoyen, J.J., Emerich, D.W., Sánchez-Díaz, M., 1992. Water stress induced changes in concentrations of proline and total soluble sugars in nodulated alfalfa (Medicago sativa) plants. Physiol. Plant. 84, 55-60. https://doi.org/10.1034/j.1399-3054.1992. 840109.x.

Jiménez, C.M., Díaz, J.B.R., 2003. A statistical model to estimate potential yields in peach before bloom. J. Am. Soc. Hortic. Sci. 128, 297-301.

Karimi, S., Yadollahi, A., Arzani, K., Imani, A., 2013. Leaf pigments help almond explants tolerating osmotic stress. Int. J. Agric. Biosyst. Sci. Eng. 7, 76-79.

Karimi, S., Yadollahi, A., Arzani, K., Imani, A., Aghaalikhani, M., 2015. Gas-exchange response of almond genotypes to water stress. Photosynthetica 53, 29-34. https:// doi.org/10.1007/s11099-015-0070-0.

Kitajima, K., Hogan, K.P., 2003. Increases of chlorophyll a/b ratios during acclimation of tropical woody seedlings to nitrogen limitation and high light. Plant Cell Environ. 26, 857-865. https://doi.org/10.1046/j.1365-3040.2003.01017.x.

Li, D., Li, C., Sun, H., Wang, W., Liu, L., Zhang, Y., 2010. Effects of drought on soluble protein content and protective enzyme system in cotton leaves. Front. Agric. China 4, 56-62. https://doi.org/10.1007/s11703-010-0102-2.

Lichtenthaler, H.K., 1987. Chlorophylls and carotenoids: pigments of photosynthetic biomembranes. Methods Enzymol. 148, 350-382. https://doi.org/10.1016/00766879(87)48036-1.

Lichtenthaler, H.K., Buschmann, C., 2005. Chlorophylls and carotenoids: measurement and characterization by UV-VIS spectroscopy. Handb. Food Anal. Chem 2-2, 171-178. https://doi.org/10.1002/0471709085.ch21.

Lisar, S.Y.S., Motafakkerazad, R., Hossain, M.M., Rahman, I.M.M., 2012. Water stress in plants: causes, effects and responses. In: Rahman, I.M.M. (Ed.), Water Stress. pp. 1-14 InTech, pp.

Mohammadkhani, N., Heidari, R., 2008. Drought-induced accumulation of soluble sugars and proline in two maize varieties. World Appl. Sci. J. 3, 448-453. https://doi.org/ $10.1104 / \mathrm{pp} .118 .2 .531$

Osaki, M., Shinano, T., Tadano, T., 1991. Redistribution of carbon and nitrogen compounds from the shoot to the harvesting organs during maturation in field crops. Soil Sci. Plant Nutr. 37, 117-128. https://doi.org/10.1080/00380768.1991.10415017.

Rauf, S., Sadaqat, H.A., 2007. Effects of varied water regimes on root length, dry matter partitioning and endogenous plant growth regulators in sunflower (Helianthus annuus L.). J. Plant Interact. 2, 41-51. https://doi.org/10.1080/17429140701422512.

Romero, P., Botía, P., 2006. Daily and seasonal patterns of leaf water relations and gas exchange of regulated deficit-irrigated almond trees under semiarid conditions. Environ. Exp. Bot. 56, 158-173. https://doi.org/10.1016/j.envexpbot.2005.01.012.

Romero, P., Navarro, J.M., García, F., Botía Ordaz, P., 2004. Effects of regulated deficit irrigation during the pre-harvest period on gas exchange, leaf development and crop yield of mature almond trees. Tree Physiol. 24, 303-312. https://doi.org/10.1093/ treephys/24.3.303.

Rosa, M., Prado, C., Podazza, G., Interdonato, R., González, J.A., Hilal, M., Prado, F.E., 2009. Soluble sugars-metabolism, sensing and abiotic stress a complex network in the life of plants. Plant Signal. Behav. 4, 388-393. https://doi.org/10.4161/psb.4.5 8294

Rouhi, V., Samson, R., Lemeur, R., Damme, Patrick Van, 2007. Photosynthetic gas exchange characteristics in three different almond species during drought stress and subsequent recovery. Environ. Exp. Bot. 59, 117-129. https://doi.org/10.1016/j. envexpbot.2005.10.001.

Šesták, Z., Catsky, J., Jarvis, P.G., 1971. Plant Photosynthetic Production: Manual of Methods. Dr. W. Junk Publishers, The Hague.

Scholander, P.F., Hammel, H.T., Brandtreet, E.T., Hemmingsen, E.A., 1965. Sap pressure in vascular plants: negative hidrostatic pressure can be measured in plants. Science 148, 339-346

Sorkheh, K., Shiran, B., Rouhi, V., Khodambashi, M., Sofo, A., 2012. Salt stress induction of some key antioxidant enzymes and metabolites in eight Iranian wild almond species. Acta Physiol. Plant. 34, 203-213. https://doi.org/10.1007/s11738-011 0819-4.

Spinelli, G.M., Snyder, R.L., Sanden, B.L., Shackel, K.A., 2016. Water stress causes stomatal closure but does not reduce canopy evapotranspiration in almond. Agric. Water Manag. 168, 11-22. https://doi.org/10.1016/j.agwat.2016.01.005.

Thalmann, M., Pazmino, D., Seung, D., Horrer, D., Nigro, A., Meier, T., Kölling, K., Pfeifhofer, H.W., Zeeman, S.C., Santelia, D., 2016. Regulation of leaf starch degradation by abscisic acid is important for osmotic stress tolerance in plants. Plant Cell 28, 1860-1878. https://doi.org/10.1105/tpc.16.00143.

Thalmann, M., Santelia, D., 2017. Starch as a determinant of plant fitness under abiotic stress. New Phytol. 214 (3), 943-951. https://doi.org/10.1111/nph.14491.

Tuteja, N., 2007. Abscisic acid and abiotic stress signaling. Plant Signal. Behav. 2, 135-138. https://doi.org/10.4161/psb.2.3.4156.

Vishwakarma, K., Upadhyay, N., Kumar, N., Yadav, G., Singh, J., Mishra, R.K., Kumar, V., Verma, R., Upadhyay, R.G., Pandey, M., Sharma, S., 2017. Abscisic acid signaling and abiotic stress tolerance in plants: a review on current knowledge and future prospects. Front. Plant Sci. 8, 1-12. https://doi.org/10.3389/fpls.2017.00161.

Wong, B.L., Baggett, K., Rye, A., 2003. Seasonal patterns of reserve and soluble carbohydrates in mature sugar maple (Acer saccharum). Can. J. Bot. 81 (8), 780-788 doi: 
10.1 139lB03-079.

von Caemmerer, S., Farquhar, G.D., 1981. Some relationships between the biochemistry of photosynthesis and the gas exchange of leaves. Planta 153, 376-387. https://doi. org/10.1007/BF00384257.

WWAP, 2015. The United Nations World Water Development Report 2015: Water for a Sustainable World. Facts and Figures. UN Water Rephttps://doi.org/10.1016/S13667017(02)00004-1. 138.

Yadollahi, A., Arzani, K., Ebadi, A., Wirthensohn, M., Karimi, S., 2011. The response of different almond genotypes to moderate and severe water stress in order to screen for drought tolerance. Sci. Hortic. (Amsterdam). 129, 403-413. https://doi.org/10. 1016/j.scienta.2011.04.007.

Yu, D.J., Kim, S.J., Lee, H.J., 2009. Stomatal and non-stomatal limitations to photosynthesis in field-grown grapevine cultivars. Biol. Plant. 53, 133-137. https://doi. org/10.1007/s10535-009-0019-x.

Zhu, Y., Taylor, C., Sommer, K., Wilkinson, K., Wirthensohn, M., 2015. Influence of deficit irrigation strategies on fatty acid and tocopherol concentration of almond (Prunus dulcis). Food Chem. 173, 821-826. https://doi.org/10.1016/j.foodchem.2014.10.10. 